\title{
ARTICLE
}

\section{Ecumenical Discussion about Deacons}

TOMI KARTTUNEN

\begin{abstract}
This article assesses the concrete contemporary ecumenical situation in the discussion of the place of deacons in the ordained ministry. This will lead us to an analysis of its relation to deep ecclesiological and even Christological aspects. The analysis begins with Vatican II and its accompanying theological renewal. This shapes the necessary background for an examination of the Lima Document and the Porvoo Declaration. The threefold ministry can be seen as instrumental in these key areas of mission, which are rooted in the Church's Trinitarian and Christological nature. If the more narrow sense of diaconia is not also present, the nature of the Eucharist as a sacrifice of love is diminished, and without the sacramental dimension, its spiritual content is thin. The ecumenical discussion of the place of deacons in the ordained ministry seems to concern how theologically and practically to embed the ministry within a sacramental communion ecclesiology. The key question is, in what way to reveal its significance as a sign and instrument of faith, hope, and love. It is therefore necessary, firstly, to come to a deeper understanding of Trinitarian communion ecclesiology and the place of diaconal ministry within it. Secondly, an understanding is needed of the practical consequences of the interplay between leitourgia, diaconia, and martyria in the mission of the church facing the suffering world today.
\end{abstract}

Since the Second Vatican Council (1962-1965) the role of deacons in the ordained ministry has got more and more ecumenical importance. When discussing deacons and deaconal ministry, we have not only the other ministries of the church(es) but also our ecclesiological understanding in focus.

Since the 19th century the western evangelical understanding of diaconia has pointed out that diaconia starts from the altar (e.g. Löhe in Schoenauer \& Henkel 2008; Hall, 2013:263). The question is, how can we draw con- 
structive and forward-looking conclusions from the vision. How the liturgical and practical service in words and deeds can be understood in the modern ecumenical ecclesiology, where since mid 20th century the church has more and more been recognised as a sign and instrument of Kingdom. This is essentially connected with the question of how the Church can credibly follow her Lord.

Our goal in this short article is to assess the concrete contemporary ecumenical situation in the discussion of the place of deacons in the ordained ministry. This will lead us to an analysis of its relation to deep ecclesiological and even Christological aspects. We begin with Vatican II and its accompanying theological renewal. This shapes the necessary background for an examination of the Lima Document and the Porvoo Declaration.

\section{The impulse of Vatican II - Ministry in a sacramental communion-ecclesiological framework}

Before the Second Vatican Council, the theology of ministry was a more or less open question in Catholic theology. For example, in late medieval Catholic theology, the ministry of the church was concentrated on the presbyterate of the priest (mono-presbyterate) and not all prince bishops were even ordained (see summarising e.g. Communion in Growth, 2017:82, paragraph 183 and footnote 217). The diaconate was a transitional ministry, with no genuine vocation of its own.

The principal ecclesiological document of the Second Vatican Council is known according to its first words as Lumen Gentium, Light of the Nations. This Dogmatic Constitution on the Church, connects the understanding of episcopal ministry as the "fullness of holy orders" to communion or eucharistic ecclesiology in the light of the New Testament revelation of God:

26. A bishop marked with the fullness of the sacrament of Orders, is 'the steward of the grace of the supreme priesthood,' especially in the Eucharist, which he offers or causes to be offered, and by which the Church continually lives and grows. This Church of Christ is truly present in all legitimate local congregations of the faithful which, united with their pastors, are themselves called Churches in the New Testament. (LG 26) 
This means that the ordained ministry is firmly anchored in eucharistic ecclesiology and Christology. Bishops are "vicars and ambassadors" of Christ, and priests and deacons alike act in the person of Christ (in persona Christi). An officeholder is not a master in his own right but a servant of the people of God: "...that duty, which the Lord committed to the shepherds of His people, is a true service, which in sacred literature is significantly called 'diakonia' or ministry." (LG 24)

The mission and ministry of the shepherds is thus in a broad sense diaconia. However, this is not to suggest that "diaconia" only refers in a general sense to the mission of the Church. In the light of communion ecclesiology, which the Second Vatican Council and the Faith and Order movement today endorse, the being of the Church is also essentially to be found in "leiturgia", liturgical life. The Church is established on the Word of God as the "light of the nations" (Lumen Gentium). She is sent into the world to witness in word and deed to Jesus Christ. Therefore, leiturgia, diakonia, and martyria belong together in the mission of the Church, in which all the faithful in Christ and the ordained ministry complement each other in their work:

17. As the Son was sent by the Father, so He too sent the Apostles... The Church has received this solemn mandate of Christ to proclaim the saving truth from the apostles and must carry it out to the very ends of the earth. ... By the proclamation of the Gospel she [The Church] prepares her hearers to receive and profess the faith. She gives them the dispositions necessary for baptism, snatches them from the slavery of error and of idols and incorporates them in Christ so that through charity they may grow up into full maturity in Christ... (LG 17)

The interplay of leiturgia, diakonia, and martyria is also biblically rooted. Jesus himself summarized the law and the prophets in the double commandment of love (Matt. 22:40). The message is clear: faith and love belong together in Christian life. As Risto Ahonen (2013:340) puts it: “Christ's self-sacrificing love has led his followers throughout the ages to ask what they could do for the benefit of their suffering neighbours."

Although love among Christians was encouraged as a priority, for example in Matthew 25, it is well known that in the Early Church it was already felt that it was of the utmost importance for the success of Christianity that 
Christians helped not only their fellow Christians but also others in need. Eucharistic ecclesiology meant in concrete terms that the bishop had the main responsibility for the diaconal task, assisted by deacons and the archdeacon as the leader of deacons (Ahonen, 1991:39-40). The Roman Empire's adoption of Christianity in the fourth century meant that the Emperor now began to take care of the less fortunate (Ahonen, 2000:211; Räisänen, 2007:50). Accordingly, "diaconia" in its more narrow philanthropic sense has been an essential dimension of Christian self-understanding and the mission of the Church in the world from the earliest times. It is unsurprising that Irenaeus already interpreted Acts 6 as the origin of the ministry of the deacon, although he did not understand it in the same way as the nineteenth-century German theologians. ${ }^{1}$

The Constantinian Turn, together with the collapse of Western Rome and the increasingly political and administrative duties of the Roman Pontiff, meant that communion ecclesiology was increasingly replaced by a hierarchical and institutional understanding of the Church (Communio Sanctorum, 2000:81-88). This approach eventually led to an individualistic and fragmented medieval ecclesiology. The Council of Trent in the 1540s and the First Vatican Council in the 1870s represent early attempts at reform. In the twentieth century a more historical, Trinitarian, biblical, and liturgical emphasis, combined with impulses from Orthodox theology and ecumenical experiences during the Second World War, saw a renewal of communion or eucharistic ecclesiology with a patristic and biblical emphasis. The increasing awareness of patristic theology, together with a more systematic historically and liturgically rooted understanding of ordained ministry within a communion ecclesiological framework, resulted in the re-establishment of the permanent diaconate by the Second Vatican Council. The context was now the challenge presented by modern post-Constantinian and post-Christian $\mathrm{Eu}-$ rope. Lumen Gentium formulates this as follows:

At a lower level of the hierarchy are deacons, upon whom hands are imposed 'not unto the priesthood, but unto a ministry of service.' For strengthened by sacramental grace, in communion with the bishop and his group of priests they serve in the diaconate of the liturgy, of the word, and of charity to the people of God... the diaconate can in the future be restored as a proper and permanent rank of the hierarchy." (LG 29) 
The threefold understanding of the tasks of a deacon (liturgy, word, charity) shows that Lumen Gentium is well aware of the character of the permanent rank of the deacons regarding the interplay of leiturgia, diakonia, and martyria.

In the more egalitarian Protestant tradition the concept of "hierarchy" is avoided, although hierarchy is at work in the organisation. ${ }^{2}$ For example, the Lutheran tradition inherited the medieval monopresbyteral understanding of ministry, and the diaconal ministry was inherent in the presbyter's office. In the Nordic countries, the historic episcopate was preserved in a Lutheran form. The Second Vatican Council and discussion about the ordination of women meant that the discussion of ordained ministry in Finland as well as in many other countries was already influenced by ecumenical impulses in the 1970s. The multilateral ecumenical discussion reached its peak in the convergence document Baptism, Eucharist and Ministry (BEM, Lima Document) which has had a significant influence on the ecumenical discussion of the threefold ministry, including the ministry of the deacon. The BEM Document is still perhaps the most important ecumenical Faith and Order document so far.

\section{BEM and the development from a functional to a constitutive understanding of ministry}

By the 1980s the mono-presbyteral understanding of ministry was subject to increasing criticism. At the same time, the threefold understanding of ministry had already been under review for a considerable period. The most recent phase of ecumenical development before BEM brought a shift from a mono-presbyteral to a more flexible understanding of the threefold ministry. This also paved the way for a new ecumenical discussion of the diaconate (Brodd, 1999:17). In the background was the extensive agreement after Vatican II concerning the fruitfulness of communion ecclesiology and the vision of the apostolicity of the life of the whole Church, with different but interdependent ministries of the members of the whole people of God in the context of contemporary challenges. BEM (1982 Ministry III A 25) concluded:

25. The traditional threefold pattern thus raises questions for all the Churches. Churches maintaining the threefold pattern will need to ask 
how its potential can be fully developed for the most effective witness of the Church in this world. In this task Churches not having the threefold pattern should also participate. They will further need to ask themselves whether the threefold pattern as developed does not have a powerful claim to be accepted by them.

The Lima Document boosted many ecumenical processes regarding the discussion of the theology of ordained ministry. For example, the Anglican-Reformed dialogue report God's Reign and Our Unity (1984) concluded by a Christological and Trinitarian understanding and presupposed that the patterns of ordained ministry must reflect and realise the ministry of Christ as it reflected the nature of the Holy Trinity. Accordingly, the various forms of ordained ministry ought to be "personal, collegial and communal" (cf. BEM Ministry III B 26; Brodd, 1999:33). This further underlines the importance given in the Lima Document to the apostolicity of the life of the whole Church and the episcopal ministry as its sign (BEM Ministry IV B 38).

However, in the ecumenical discussions the deacon was still seen primarily as having a servant role, not only in relation to the bishop but also in relation to the priest. This was the case not only in Catholic-Orthodox dialogue but also, for example, in Anglican-Reformed dialogue (Brodd, 1999:37). Although the central role of the pastor (mono-presbyteriate) was criticised and the discussion proceeded, the priest/pastor was often the norm or the focus in Protestant circles. It is only the last few decades which have seen a change in the discussion. Only twenty years ago Sven-Erik Brodd (1999:11) could call the diaconate "an escalating phenomenon" from an ecumenical perspective. Now it seems that while no rapid change has occurred in the last two decades, some progress has been made.

The key theological question appears to concern whether the ordained ministry is understood functionally or constitutively. This is connected with the understanding of the sacramentality of the Church, and especially the concrete structures of sacramental ecclesiology. In the background is a shift in the understanding of the diaconate less from a canonical and institutional, but from a communion ecclesiological, perspective (Brodd, 1999:37). This approach underlines ordination as an instrumental and effective, christologically and pneumatologically rooted act, which undertakes and transmits the Church's apostolic legacy. In this context, ordination is understood anamnet- 
ically and epicletically as the transmission of the gifts of the Holy Spirit specific to each ministry, and as participation in the mission of the Triune God in the building up of his Church, and less as the authorisation and giving of special power to the individual.

In the Finnish context, the discussion based on BEM has also served as a catalyst. Since the late eighteenth century, the influence of the Enlightenment and pietism led to the development of a functionalist understanding of ministry, based on the needs of the congregation, among the Protestant Churches (Brodd, 1999:38). There were exceptions: Wilhelm Löhe (180872) emphasised the ecclesiological and eucharistic basis of diaconia, but the main trend was clear (Ahonen, 1991:60-61). The Finnish situation differed from the German, for example, in emphasising the diaconal ministry's ecclesiological and Christological basis. For example, in his Handbook for Diaconia (1938) Bishop Eino Sormunen underlined that diaconal service began at the altar (Ahonen, 1991:118-119). In the context of the Nordic Lutheran majority churches, with their rich and developing financial resources and their self-understanding as "folk churches", an increasingly functionalist view of the ministry nevertheless emerged. However, ecumenical development and the churches' identity problems, together with the discussion about opening the ordained ministry to women, led to a deeper understanding of the ecclesiological and Christological basis of the ordained ministry as part of the constitution of the Church.

In the light of the sacramental communion ecclesiological approach, it was possible to ground the threefold ministry in the context of leiturgia, martyria, and diakonia as core functions in the life of the Church. The threefold ministry can be seen as instrumental in these key areas of mission, which are rooted in the Church's Trinitarian and Christological nature (Brodd, 1999:38). If the more narrow sense of diaconia is not also present, the nature of the Eucharist as a sacrifice of love is diminished, and without the sacramental dimension, its spiritual content is thin (Repo, 2007:139). The Christological basis of the diaconal ministry was strengthened in Finnish discussion by the paradigmatic idea of the Finnish Luther research inspired by Tuomo Mannermaa and his students, which saw the presence of Christ in faith (in ipsa fide Christus adest) as the basis of the faith and love which in Christ belong incarnationally together. Thus, diaconia is concretely placed at the centre of the faith and life of the Christian community and local parish (Ahonen, 1991:120). 
The diaconate was therefore seen as open for renewal as a more liturgical and catechetical ministry. In 1985 the General Synod of the Evangelical Lutheran Church of Finland acknowledged that the application of a threefold understanding of ordained ministry was possible (Ahonen, 1991:125). However, although the ordination rite of the deacons in the Evangelical Lutheran Church of Finland clearly implicates a threefold understanding of the ordained ministry, this has not yet generally lead to practical conclusions regarding the threefold understanding. Even an opposite position has got more weight during the last decades. (Malkavaara, 2015:198-202,223.)

The liturgical functions of deacons have expanded since the 1970s in Finland, and the service book for the Lutheran Mass, which was revised in 2000, focused on the liturgical role of deacons in assisting in the administration of the Eucharist, in leading intercessions, serving as readers, and in giving the dismissal. The tradition that deacons may administer (not consecrate) Holy Communion to the sick is also presented in the official guidelines, and is practised in some places. Since the 1950s the official committees of the church have underlined that the ministry of the deacon is an essential part of the ministry of the church and that its liturgical and catechetical functions should be strengthened. Yet the official renewal of the diaconate has met a slow reception. Some still regard the diaconal ministry as a lay ministry.

In the most recent phase, in May 2016, the ELCF Bishops' Conference recommended concerning the ordination of deacons: "The bishop of each diocese ordains deacons in their diocese in accordance with the Church handbook." Deacons receive ordination training and a licence, and dioceses keep a register of deacons. They may wear a green shirt and a stole as a sign of their ministry (Suositus, 2016).

\section{The Porvoo process and other ecumenical discussions today: "The diaconate - an escalating ecumenical phenomenon"?}

The Porvoo Common Statement and its implementation sheds especially exciting light on the ecumenical discussion of deacons. The Anglican churches had retained the transitional diaconate, while the Lutheran churches had been influenced by the caritative emphasis of the nineteenth century diaconal movement. The sacramental communion ecclesiology which the Porvoo 
Common Statement manifests led to the theology of ordained ministry being placed within a new ecumenical, patristic, and biblical context. The Porvoo Declaration (1996) committed the member churches "to work towards a common understanding of diaconal ministry".

In 1999 Sven-Erik Brodd identified a "re-orientation, reconsideration and even introduction of the ordained diaconate" not only among the $\mathrm{Lu}-$ theran Porvoo Churches but also as a global ecumenical trend. According to Brodd (1999:42-43) this "very often leads to an actual convergence between Churches of various traditions around the world. ... The rediscovery of the ecclesial threefold structure of leiturgia, diaconia and martyria also paves the way for a theological convergence between Churches which have the threefold ministry and those which do not. In this dialogue, the deacon's ministry plays an important role."

However, the development has not only been linear. The emphasis on renewal seems less clear than fifteen or twenty years ago. Christine Hall saw some years ago that there was a perception of the diaconate in the 1980s and 90s as an escalating ecumenical phenomenon in a wide variety of churches, for example, among Anglicans, Lutherans, Methodists, and Roman Catholics. The Orthodox and Oriental Orthodox churches should also be mentioned here. Yet Hall identifies three counter-currents which "prevented the diaconate from fulfilling its perceived promise": 1) The mono-presbyterate was still evident in many churches; 2) "diaconia" was a problematic concept, especially in the English-speaking world; and 3) the ecclesiology of the diaconate seemed to be somewhat vague (Hall, 2013:262-267). The understanding of the diaconate in the context of sacramental communion ecclesiology should, therefore, be strengthened.

The difficulties in recognising the influence of the mono-presbyterate as historically conditioned and not as a strictly necessary understanding of ordained ministry in the Lutheran tradition is exemplified by the discussion about the translation of the term "diaconal ministry". The term may refer either to "the ministry of the deacon" or to a more general kind of lay ministry in English. The formulation was originally a compromise, and had not previously been part of regularly used Anglican terminology. However, in discussions about the problems posed by translating the term "diaconal ministry," it was finally agreed that the term should also refer to "the ministry of the deacon" in the threefold framework of bishop, priest, and deacon (Pädam, 
2013:301). ${ }^{3}$ This may be seen as a consequence of the principle that the intention of the Porvoo Declaration is the recognition of ordained ministries and this recognition includes only ordained deacons (Brodd, 1999:26).

Tiit Pädam's doctoral thesis presents a comparative ecclesiological investigation of the ordination of deacons in the churches of the Porvoo Communion (Pädam, 2011). Pädam concludes that through the authorisation of new ordinals the Porvoo churches have grown closer to one another theologically. However, there are significant gaps in the factual embodiment of this shared theology. The reception and authoritative character of the decisions made regarding the Communion is hampered by the fact that it has no formal structures for decision making. This complicates the practical recognition of ministries (Pädam, 2011:373-374). Pädam later focused on the fact that the other Porvoo churches had diverged from the Evangelical Lutheran Church in Denmark in establishing the deacon's ministry within the ordained ministry (Pädam, 2016:171). It remains encouraging, however, that all the Porvoo churches share an ecclesiologically motivated understanding of the deacon's ministry. Pädam suggests that a comprehensive comparison of the positions of the Porvoo churches should be undertaken. This might enable the identification of essential features and propose common ground for the construction of possible future solutions. Such a process might even include the creation of structures to support its implementation in the practical life of the churches involved (Pädam, 2013:309-310).

\section{Where the discussion stands today}

Discussion of the role and function of the deacons in the church, strongly stimulated by the Second Vatican Council, has been turbulent to the ecumenical discussion about the ministry. It appears then that there is an acute need to reflect on and draw conclusions from the insight BEM (Ministry III C 31) formulates as follows: "Deacons represent to the Church it's calling as servant in the world. By struggling in Christ's name with the myriad needs of societies and persons, deacons exemplify the interdependence of worship and service in the Church's life." On the one hand, the ministry of the deacon is recognised as ministry between liturgy and more traditional diaconal work; on the other, the relevance of the diaconal ministry is not always fully recognised in practice. 
The ecumenical discussion of the place of deacons in the ordained ministry seems to concern how theologically and practically to embed the ministry within a sacramental communion ecclesiology. The key question is, in what way to reveal its significance as a sign and instrument of faith, hope, and love. In the light of sign ecclesiology there have been problems to draw constructive and forward-looking conclusions from the vision that "diaconia" starts from the altar, and includes both liturgical and practical service in words and deeds. This is essentially connected with the question of how the Church can credibly follow her Lord. In the light of this ecclesiology, the ministry of the deacon should reflect the balance of Trinitarian unity and the distinctiveness of Trinity's persons. Moreover, the ordained ministry participates in the ministry of Christ the Deacon.

It is therefore necessary, firstly, to come to a deeper understanding of Trinitarian communion ecclesiology and the place of diaconal ministry within it. Secondly, an understanding is needed of the practical consequences of the interplay between leitourgia, diakonia, and martyria in the mission of the church facing the suffering world today in the light of faith, hope, and love. As it is well known in ecumenical discussions, research in patristic texts may afford further insights here. The discussion of the contribution of John Collins and his challenge to a one-sided caritative understanding of the deacon's ministry serves as a good example of the ecumenical relevance of scholars' input in this respect (Cf. Collins 1990; about the Collins-debate Malkavaara 2015 and Latvus 2017). 


\section{Footnotes}

1 According to Ahonen, 1991:24, it is clear that Acts 6 has inspired the later understanding of the ministry of the deacon, although a direct historical influence cannot be traced.

2 For example, the CPCE document Ministry, Ordination, Episkopé and Theological Education, 2013, states: "50. For Protestants, the most problematic issue with the threefold ministry according to BEM is the hierarchical gradation that can be observed in the Anglican, Orthodox and Roman Catholic Churches." Cf. the Church of Sweden document Det kyrkliga ämbetet, 1990:40, affirms that the threefold

\section{References}

Ahonen, R. (1991). Diakonaatin uudistus. Kirkon tutkimuskeskus, sarja A, n:o 56. Tampere: Kirkon tutkimuskeskus.

Ahonen, R. (2000). The Diaconate and Ecclesiology. - G. Borgegård, O. Fanuelson \& C. Hall (eds.), The Ministry of the Deacon. 2. Ecclesiological Explorations. Uppsala: Nordic Ecumenical Council, 207-238.

Ahonen, R. (2013). The Renewal of the Diaconate and the Holistic Mission of the Church. International Journal for the Study of the Christian Church, 13(4), 327-341. https://doi.org/10.1080/14742 25X.2013.869706

BEM (1982). Baptism, Eucharist and Ministry. Faith and Order Paper No. 111. Geneva: World Council of Churches.

Brodd, S.-E. (1999). An Escalating Phenomenon: The Diaconate from an Ecumenical Perspective. - G. Borgegård \& C. Hall (eds.), The Ministry of the Deacon. 1. Anglican - Lutheran Perspectives. Uppsala: Nordic Ecumenical Council, 11-50.

Communio Sanctorum (2000). Communio Sanctorum. Die Kirche als Gemeinschaft der Heiligen. Bilaterale Arbeitsgruppe der Deutschen Bishofskonferenz und der Kirchenleitung der Vereinigten Evange- ministry is God's gift to the Church; that is the threefold ministry is understood non-hierarchically, with each "equally valuable" part of the ordained ministry having its independent areas of responsibility which are closely related, but some tasks which are exclusive. For example, the task of administering the sacraments is reserved for bishops and priests and the right to ordain for bishops.

3 Cf. Vikström, 2011:554-555, who criticises the translation "diakonin virka" in Finnish, which means "the ministry of the deacon".

lisch-Lutherischen Kirche Deutschlands. Frankfurt am M./Paderborn: Bonifatius/ Lembeck.

Communion in Growth (2017). Communion in Growth. Declaration on the Church, Eucharist, and Ministry. A Report from the Lutheran-Catholic Dialogue Commission for Finland. Evangelical Lutheran Church of Finland Catholic Church in Finland. Helsinki: Evangelical Lutheran Church of Finland \& Catholic Church in Finland.

Collins, J. (1990). Diakonia. Re-interpreting the ancient sources. Oxford: Oxford University Press. https://doi.org/10.1093/ acprof:oso/9780195396027.001.0001

Hall, Chr. (2013). Research on the diaconate: a retrospective view of promise and challenge. International Journal for the Study of the Christian Church, 13(4), 258-269. https://doi.org/10.1080/14742 25X.2014.892730

Det kyrkliga ämbetet (1990). Det kyrkliga ämbetet. Betänkande av kyrkkoordningskommittén. Uppsala: Svenska kyrkan.

Latvus, K. (2017). Diaconia as Care for the Poor? Critical Perspectives on the Development of Caritative Diaconia. Kirkon tutki- 
muskeskuksen verkkojulkaisuja, 53. Tampere: Kirkon tutkimuskeskus.

Malkavaara, M. (2015). Diakonia ja diakonivirka. Suomen ev.-lut. kirkon julkaisuja 26. Kirkko ja toiminta. Helsinki: Kirkkohallitus.

Ministry, Ordination, Episkopé (2013). Ministry, Ordination, Episkopé and Theological Education. Leuenberg Documents 13. M. Bünker \& M. Friedrich (eds.) Mandated by the Council of the Community of Protestant Churches in Europe. Leipzig: Evangelische Verlagsanstalt Leipzig.

Pädam, T. (2011). Ordination of Deacons in the Churches of the Porvoo Communion. A Comparative Investigation in Ecclesiology. Uppsala.

Pädam, T. (2013) The Diaconate after the Signing of the Porvoo Declaration: An Overview of Methods and Hermeneutics. International Journal for the Study of the Christian Church, 13(4), 300-311. https:// doi.org/10.1080/1474225X.2013.869379

Pädam, T. (2016). Developments in the Diaconate among the Porvoo Churches. -
B. Fagerli, L. Nathaniel \& T. Karttunen (eds.), Towards Closer Unity. Communion of the Porvoo Churches 20 Years. Porvoo: Porvoo Communion of Churches.

Repo, M. (2007). Diakonian virka ekumeenisena haasteena. - K. Latvus \& A. Elenius (eds.), Auttamisen teologia. Helsinki: Kirjapaja, 122-139.

Räisänen, H. (2007). Raamattu, varhaiskirkko ja diakonia. - K. Latvus \& A. Elenius (eds.), Auttamisen teologia. Helsinki: Kirjapaja, 37-51.

Schoenauer, H \& Henkel, J. (2008). „Alle Diakonie geht vom Altar aus" Theologie und Praxis der Diakonie im ökumenischen Dialog. Bonn: Schiller Verlag.

Suositus (2016): Suositus diakonian virkaan vihkimiselle. Piispainkokous. http:// sakasti.evl.fi/sakasti.nsf/0/A78B3114D64D8273C22577030039EE08/\$FILE/ Suositus-diakonian-virka.pdf - Retrieved 18.11.2018.

Vikström, E. (2011). Den diakonala tjänsten. Teologinen Aikakauskirja, 116(6), 554-557.

\section{Author}

Tomi Karttunen

Rev., Dr., Adjunct professor

School of Theology, University of Eastern Finland

tomi.karttunen@evl.fi 